\title{
A single exposure to iron oxide nanoparticles attenuates antigen-specific antibody production and T-cell reactivity in ovalbumin-sensitized $\mathrm{BALB} / \mathrm{c}$ mice
}

\author{
Chien-Chang Shen' \\ Chia-Chi Wang' \\ Mei-Hsiu Liao ${ }^{2}$ \\ Tong-Rong Jan' \\ 'Department and Graduate Institute \\ of Veterinary Medicine, \\ School of Veterinary Medicine, \\ National Taiwan University, Taipei, \\ Taiwan; ${ }^{2}$ Division of Isotope \\ Application, Institute of Energy \\ Research, Taoyuan, Taiwan
}

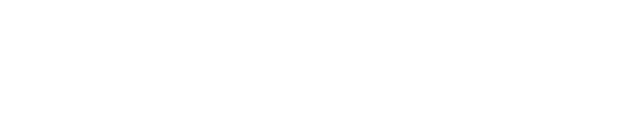

Background: Superparamagnetic iron oxide nanoparticles have been used in clinical applications as a diagnostic contrasting agent. Previous studies showed that iron oxide nanoparticles deposited in the liver and spleen after systemic administration. The present study investigated the effect of iron oxide nanoparticles on antigen-specific immune responses in mice sensitized with the $T$ cell-dependent antigen ovalbumin (OVA).

Methods: BALB/c mice were intravenously administered with a single dose of iron oxide nanoparticles (10-60 mg Fe/kg) 1 hour prior to OVA sensitization, and the serum antibody production and splenocyte reactivity were examined 7 days later.

Results: The serum levels of OVA-specific $\operatorname{IgG}_{1}$ and $\mathrm{IgG}_{2 \mathrm{a}}$ were significantly attenuated by treatment with iron oxide nanoparticles. The production of interferon- $\gamma$ and interleukin- 4 by splenocytes re-stimulated with OVA in culture was robustly suppressed in mice administered with iron oxide nanoparticles. The viability of OVA-stimulated splenocytes was also attenuated. In contrast, treatment with iron oxide nanoparticles did not affect the viability of splenocytes stimulated with concanavalin A, a T-cell mitogen.

Conclusion: Collectively, these data indicate that systemic exposure to a single dose of iron oxide nanoparticles compromises subsequent antigen-specific immune reactions, including the serum production of antigen-specific antibodies, and the functionality of $\mathrm{T}$ cells.

Keywords: iron oxide nanoparticle, antigen-specific, immune, ovalbumin

\section{Introduction}

Iron oxide nanoparticles have been used in various fields of biomedical research and clinical applications, including magnetic resonance imaging, cell labeling, cancer therapy and drug delivery. ${ }^{1-4}$ In particular, Resovist ${ }^{\circledR}$, a preparation of carboxydextrancoated superparamagnetic iron oxide nanoparticles, has been approved as a diagnostic contrast agent in many countries. Previous studies have shown that iron oxide nanoparticles can be taken up by the reticuloendothelial system upon systemic administration, with the liver and spleen being the major organs of drug deposition. ${ }^{5-7}$ In addition, immune organs have been shown to be the main sites for the deposition of other nanoparticles following systemic exposure. ${ }^{89}$ Hence, the interaction between nanoparticles and immune cells and the consequences of such interactions are relevant issues in addressing the potential health impact of iron oxide and other nanoparticles.

The influence of iron oxide nanoparticles on macrophage functions has been previously reported. For example, iron oxide nanoparticles have been shown to 
suppress the phagocytic activity of Raw 264.7 cells, a murine macrophage line. ${ }^{10}$ Exposure of primary macrophages to iron oxide nanoparticles in culture resulted in a marked induction of oxidative stress and apoptosis. ${ }^{11}$ Furthermore, animal studies have shown that intratracheal instillation of mice with iron oxide nanoparticles induced a marked infiltration of inflammatory cells in the lungs and elevated levels of proinflammatory cytokines, including interleukin (IL)-1, IL-6 and tumor necrosis factor- $\alpha$ in the bronchoalveolar lavage fluid. ${ }^{12}$ These results clearly demonstrated that the functionality of macrophages was modulated by iron oxide nanoparticles upon in vitro and in vivo exposure. In addition to macrophages, a recent study has shown that $\mathrm{T}$ cells were another target in the immune system sensitive to iron oxide nanoparticles. A single intravenous administration of iron oxide nanoparticles to normal mice increased the number of both $\mathrm{CD}^{+}$and $\mathrm{CD}^{+}$cells in the peripheral blood, and the serum levels of IL-2 and interferon (IFN)- $\gamma$, two critical cytokines predominantly released by $\mathrm{T}$ cells. ${ }^{13}$ Together, these reports demonstrated that exposure to iron oxide nanoparticles affected some aspects of immune reactions mediated by macrophages and $\mathrm{T}$ cells. However, it is currently unclear if antigen-specific immunity is influenced by iron oxide nanoparticles.

In light of the available evidence showing the impacts of iron oxide nanoparticles on the functionality of macrophages and $\mathrm{T}$ cells, the objective of the present study was to investigate the effect of iron oxide nanoparticles on antigen-specific immune responses in a murine model sensitized with ovalbumin (OVA), a T cell-dependent antigen. ${ }^{14,15}$

\section{Materials and methods}

\section{Reagents and chemicals}

All reagents were purchased from Sigma (St Louis, MO) unless otherwise stated. Enzyme-linked immunosorbent assay (ELISA) sets for cytokine measurement were purchased from BD Biosciences (San Diego, CA). Fetal bovine serum (FBS) and cell culture supplies were purchased from Hyclone (Logan, UT). Resovist ${ }^{\circledR}$ (Schering AG, Berlin, Germany), a commercial preparation of carboxydextran-coated iron oxide nanoparticles containing $28 \mathrm{mg} \mathrm{Fe} / \mathrm{mL}$, was used in the present study.

\section{Animals}

Male BALB/c mice (5 weeks old) were obtained from BioLasco (Ilan, Taiwan). On arrival, mice were randomly transferred to plastic cages containing aspen bedding and quarantined for at least 1 week. Mice were housed in a temperature $\left(22^{\circ} \mathrm{C} \pm 2{ }^{\circ} \mathrm{C}\right)$, humidity $(50 \% \pm 20 \%)$ and light (12-hour light/dark cycle)-controlled environment. Food and water were supplied ad libitum.

\section{Animal experiment protocol}

A previously described sensitization protocol was employed with minor modifications. ${ }^{16,17}$ Briefly, the mice were randomly divided into the following groups (3-5 animals/group): naïve (NA), ovalbumin-sensitized (OVA), vehicle-treated and OVA-sensitized (VH), and iron oxide nanoparticle-treated and OVA-sensitized (Figure 1). Except for NA and OVA groups, the mice were administered intravenously with a single dose of iron oxide nanoparticles (10, 30 and $60 \mathrm{mg} \mathrm{Fe} / \mathrm{kg}$; $0.2 \mathrm{~mL} / \mathrm{mouse}$ ) and/or vehicle (VH; saline; $0.2 \mathrm{~mL} / \mathrm{mouse}$ ). Except for the NA group, the mice were sensitized 1 hour after drug administration with OVA by intraperitoneal injection using a sensitization solution containing $100 \mu \mathrm{g}$ OVA plus $1 \mathrm{mg}$ alum (as adjuvant) in saline $(250 \mu \mathrm{L} / \mathrm{mouse})$. The mice were sacrificed 7 days after OVA sensitization. Blood samples from individual mice were collected by cardiac puncture, and the serum was obtained by centrifugation of the coagulated blood at $3000 \times \mathrm{g}$ for $15 \mathrm{~min}$. All animal experiments were approved by the Institutional Animal Care and Use Committee of the National Taiwan University.

\section{Splenocyte culture}

Spleens from the mice of the same group were aseptically isolated, pooled and made into single cell suspensions as described previously. ${ }^{18}$ Splenocytes were cultured in RPMI 1640 medium supplemented with $100 \mathrm{U} / \mathrm{mL}$ penicillin,

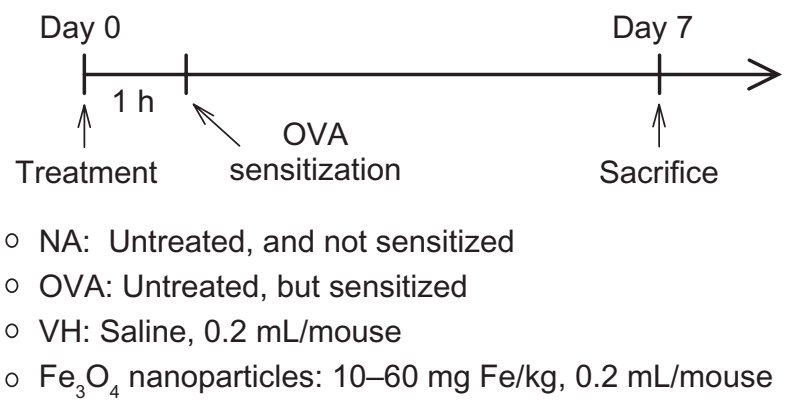

Figure I Protocol of iron oxide nanoparticle administration and OVA sensitization. $\mathrm{BALB} / \mathrm{c}$ mice were randomly divided into the following groups (3-5 animals/group): naïve (NA), ovalbumin-sensitized (OVA), vehicle-treated and OVA-sensitized (VH), and iron oxide nanoparticle-treated and OVA-sensitized. Except for NA and OVA groups, the mice were administered intravenously with a single dose of iron oxide nanoparticles (10, 30 and $60 \mathrm{mg} \mathrm{Fe} / \mathrm{kg} ; 0.2 \mathrm{~mL} /$ mouse) and/or vehicle ( $\mathrm{VH}$; saline; $0.2 \mathrm{~mL} /$ mouse). Except for the NA group, the mice were sensitized I hour after drug administration with ovalbumin (OVA) by intraperitoneal injection using a sensitization solution containing $100 \mu \mathrm{g}$ OVA plus I mg alum (as adjuvant) in saline $(250 \mu \mathrm{L} /$ mouse). Mice were sacrificed 7 days after OVA sensitization, and the spleen and blood were harvested for further experimentation. 
$100 \mu \mathrm{g} / \mathrm{mL}$ streptomycin, and $10 \%$ heat inactivated FBS. In all cases, splenocytes were cultured at $37^{\circ} \mathrm{C}$ in $5 \% \mathrm{CO}_{2}$.

\section{Measurement of OVA-specific IgG by enzyme-linked immunosorbent assay (ELISA)}

OVA-specific $\operatorname{IgG}_{1}$ and $\operatorname{IgG}_{2 \mathrm{a}}$ were measured as previously described. ${ }^{19}$ In brief, ELISA plates were coated with $0.05 \%$ OVA in coating buffer $\left(0.1 \mathrm{M} \mathrm{NaHCO}_{3}\right)$, and blocked with $1 \%$ bovine serum albumin in phosphate-buffered saline (PBS) containing $0.05 \%$ Tween 20 (PBST). After washing with PBST, serum samples were placed into wells $(50 \mu \mathrm{L} /$ well $)$ and incubated for 1 hour. After another washing, horse radish peroxidase-conjugated anti-mouse $\mathrm{IgG}_{1}$ and $\mathrm{IgG}_{2 \mathrm{a}}$ was added (50 $\mu \mathrm{L} /$ well) and incubated for 1 hour. Lastly, wells were washed and a tetramethylbenzidine solution $(50 \mu \mathrm{L} /$ well $)$ was added for colorimetric detection of bound peroxidase conjugate. The reaction was stopped by adding $150 \mu \mathrm{L}$ per well of $3 \mathrm{~N} \mathrm{H}_{2} \mathrm{SO}_{4}$. The optical density (OD) was measured at $450 \mathrm{~nm}$ using a microplate reader (Molecular Devices, Inc., Sunnyvale, CA). As the assay does not include a standard curve, the results are expressed as OD values.

\section{Measurement of splenocyte viability}

The viability of splenocytes was determined by the 3-(4,5dimethylthiazol-2-yl)-2,5-diphenyl-tetrazolium bromide (MTT) assay as previously described.$^{20}$ Briefly, splenocytes $\left(5 \times 10^{6}\right.$ cells $\left./ \mathrm{mL}\right)$ were cultured in triplicate $(100 \mu \mathrm{L} /$ well $)$ in 96-well plates in the absence (no stimulation) or presence of OVA $(50 \mu \mathrm{g} / \mathrm{mL})$ for 72 hours or concanavalinA (ConA; $5 \mu \mathrm{g} / \mathrm{mL}$ ) for 48 hours. An MTT stock solution ( $5 \mathrm{mg} / \mathrm{mL}$ in PBS) was added to each well $(10 \mu \mathrm{L} /$ well $)$ and incubated for 4 hours. The formed formazan was then dissolved by adding $200 \mu \mathrm{L} 0.1 \mathrm{~N}$ acid-isopropanol per well and shaken gently. OD was measured at $570 \mathrm{~nm}$, and at $630 \mathrm{~nm}$ as a background reference, using a microplate reader.

\section{Cytokine measurement}

The splenocytes $\left(5 \times 10^{6}\right.$ cells $\left./ \mathrm{mL}\right)$ were cultured in quadruplicate in 48 -well plates $(0.25 \mathrm{ml} /$ well $)$, and stimulated with OVA $(50 \mu \mathrm{g} / \mathrm{mL})$ for 72 hours or ConA $(5 \mu \mathrm{g} / \mathrm{mL})$ for 48 hours. The supernatants were collected and quantified for IL-4 and IFN- $\gamma$ by ELISA as previously described. ${ }^{19}$

\section{Flow cytometric analysis of splenocyte cellularity}

Splenocytes obtained from each group were stained with rat anti-mouse CD4 conjugated with fluorescein isothiocyanate
(FITC) and rat anti-mouse CD8 and B220 conjugated with PE-Cy5 antibodies (BioLegend, San Diego, CA) in PBS containing $2 \%$ fetal bovine serum (FBS). After washing, the single cell fluorescence of 10,000 cells for each sample was measured by a flow cytometer (BD FACSCalibur, San Jose, CA). Data were analyzed using the software Flowjo 5.7 (Tree Star Inc, Ashland, OR).

\section{Statistical analysis}

The mean \pm standard error (SE) was determined for each treatment group in the individual experiments. Homogeneous data were evaluated by a parametric analysis of variance, and Dunnett's two-tailed $t$-test was used to compare treatment groups to the control group. $P$ value $<0.05$ was defined as statistical significance.

\section{Results}

\section{Exposure to a single dose of iron oxide nanoparticles attenuated antigen-specific antibody production}

Mice were intravenously administered with a single dose of iron oxide nanoparticles (10-60 mg Fe/ $\mathrm{kg}$ of body weight) and then sensitized with OVA (Figure 1). The doses were chosen on the basis of previous studies using a similar range for magnetic resonance imaging of the liver and musculoskeletal infections in rats..$^{21,22}$ To measure humoral responses, serum samples from individual mice were collected 7 days after the OVA sensitization and OVA-specific antibodies were examined as previously described.$^{19} \mathrm{~A}$ marked increase in the serum levels of OVAspecific $\operatorname{IgG}_{1}$ and $\operatorname{IgG}_{2 \mathrm{a}}$ was observed in OVA-sensitized mice, as compared to non-sensitized naïve mice (Figure 2A and B; OVA versus NA; $P<0.05$ ), indicating a successful induction of humoral responses. No significant difference between the VH and OVA groups was observed (Figure 2A and $\mathrm{B}$; VH versus OVA), demonstrating that the $\mathrm{VH}$ treatment per se has no effect on the antibody responses. The production of OVA-specific $\mathrm{IgG}_{1}$ was attenuated by the doses of 30 and $60 \mathrm{mg} \mathrm{Fe} / \mathrm{kg}$ (Figure 2A; $P<0.05$ ), whereas the low dose $(10 \mathrm{mg} \mathrm{Fe} / \mathrm{kg})$ was ineffective. These results showed a trend of dose-dependency by iron oxide nanoparticles on $\mathrm{IgG}_{1}$ production. Iron oxide nanoparticles (10-60 mg Fe/kg) also demonstrated a suppressive effect on the serum production of OVA-specific $\operatorname{IgG}_{2 \mathrm{a}}$ (Figure 2B; $P<0.05$ ), in which the magnitude of suppression by all three doses was comparable, and no dose-dependency was observed. 

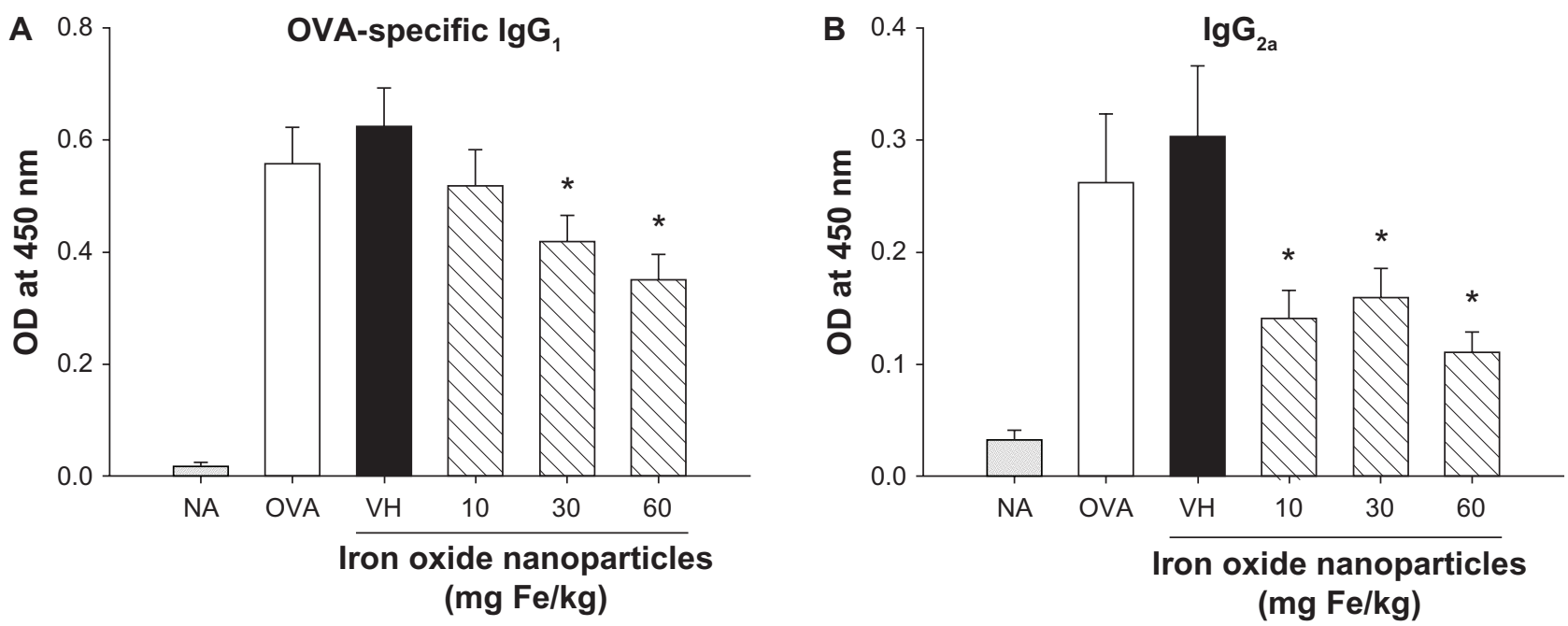

Figure 2 Attenuation by iron oxide nanoparticles of the serum production of OVA-specific $\lg G_{1}$ and IgG . Mice were treated with iron oxide nanoparticles and sensitized with OVA as depicted in Figure I. The serum levels of OVA-specific $\lg G_{1}$ and $\lg G_{2 a}$ were measured by ELISA.

Note: Data are expressed as the mean \pm SE of 9-15 samples pooled from 3 independent experiments. *P $<0.05$ compared to the $\mathrm{VH}$ group.

Abbreviations: OVA, ovalbumin; ELISA, enzyme-linked immunosorbent assay; SE, standard error; VH, vehicle treated group; OD, optical density.

\section{Iron oxide nanoparticles attenuated antigen-induced $\mathrm{T}$ cell reactivity}

As $\mathrm{T}$ cells play a pivotal role in antigen-specific humoral responses, we examined the effect of iron oxide nanoparticles on the functionality of $\mathrm{T}$ cells. Splenocytes isolated from naïve and OVA-sensitized mice were stimulated with OVA $(50 \mu \mathrm{g} / \mathrm{mL})$ in culture for 72 hours to induce antigenspecific cytokine production. As expected, the amount of cytokines produced by splenocytes of the non-sensitized mice (NA) was very low, and the OVA stimulation markedly increased the production of IL-4 and IFN- $\gamma$ by splenocytes of OVA-sensitized mice (Figure 3A and B; OVA versus
NA; $P<0.05)$. The production of IFN- $\gamma$ was significantly suppressed in all iron oxide nanoparticle-treated groups with a comparable magnitude of inhibition between the 3 doses (Figure 3A; $P<0.05$ ). The production of IL-4 was also markedly attenuated by the doses of 30 and $60 \mathrm{mg} \mathrm{Fe} / \mathrm{kg}$ (Figure 3B; $P<0.05)$, whereas the low dose $(10 \mathrm{mg} \mathrm{Fe} / \mathrm{kg}$ ) was ineffective. As the expression of antigen-induced cytokines was suppressed by iron oxide nanoparticle treatment, the viability of splenocytes was further examined. As shown in Figure 4A, the viability of the OVA-stimulated splenocytes was attenuated in all three iron oxide nanoparticle-treated groups $(P<0.05)$. The cellularity of splenocytes was also
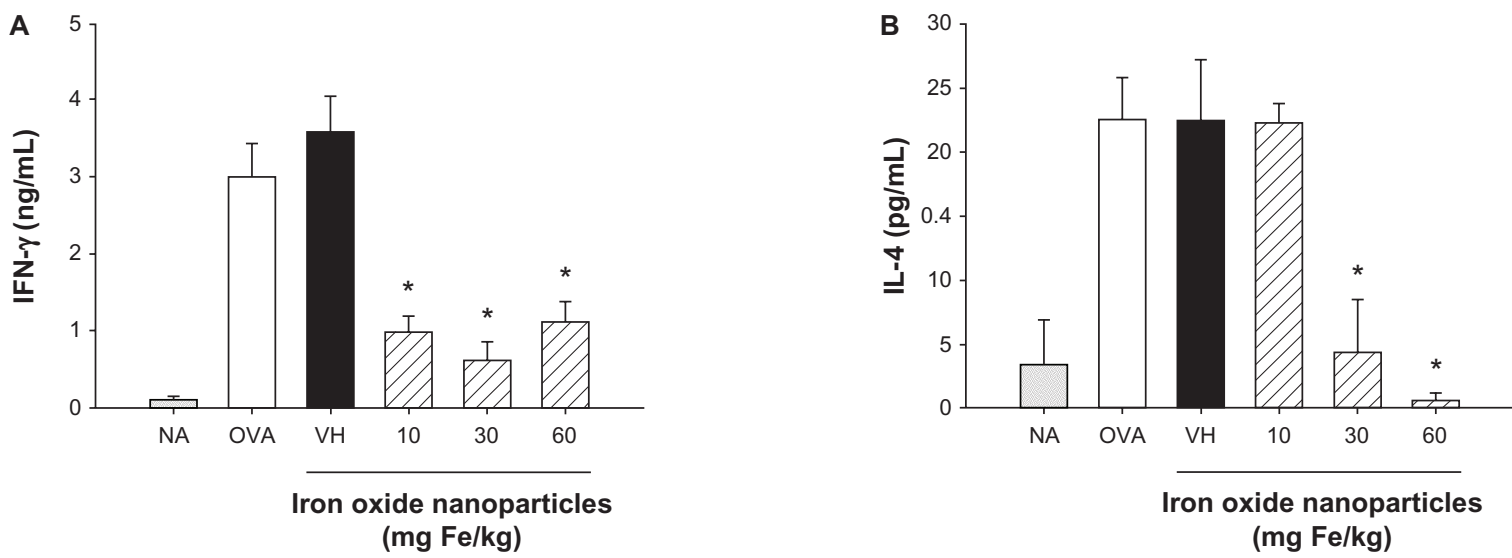

Figure 3 Attenuation by iron oxide nanoparticles of antigen-induced production of IFN- $\gamma$ and IL-4 by splenocytes. Mice were treated with iron oxide nanoparticles and sensitized with OVA as depicted in Figure I. The splenocytes $\left(5 \times 10^{6}\right.$ cells $\left./ \mathrm{mL}\right)$ isolated from each group of mice were re-stimulated with OVA $(50 \mu \mathrm{g} / \mathrm{mL})$ in culture for 72 hours to induce cytokine production. The levels of (A) IFN- $\gamma$ and (B) IL-4 in the supernatants were measured by ELISA.

Notes: Data are expressed as the mean \pm SE of quadruplicate cultures. $* P<0.05$ compared to the VH control. Results are a representative of 3 independent experiments.

Abbreviations: OVA, ovalbumin; ELISA, enzyme-linked immunosorbent assay; SE, standard error; VH, vehicle treated group. 

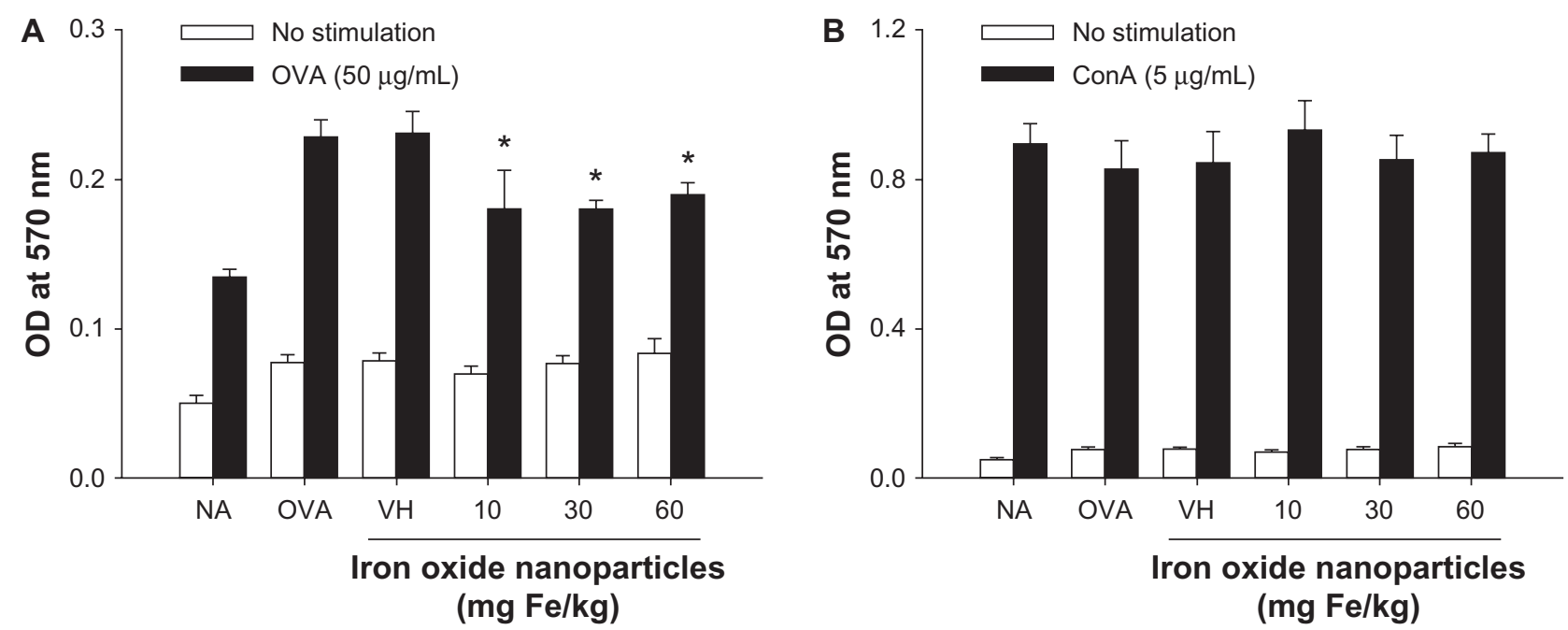

Figure 4 Effect of iron oxide nanoparticles on the viability of splenocytes. Mice were treated with iron oxide nanoparticles and sensitized with OVA as depicted in Figure I. The splenocytes $\left(5 \times 10^{6}\right.$ cells $\left./ \mathrm{mL}\right)$ isolated from each group of mice were cultured in the absence or presence of OVA $(50 \mu g / \mathrm{mL})$ for $72 \mathrm{hours}$ or ConA $(5 \mu \mathrm{g} / \mathrm{mL})$ for 48 hours, and the viability of splenocytes was determined by an MTT assay.

Notes: Data are expressed as the mean \pm SE of quadruplicate cultures. $* \mathrm{P}<0.05$ as compared with the matched $\mathrm{VH}$ group. Results are representative of 3 independent experiments. Abbreviations: OVA, ovalbumin; ConA, concanavalin A; MTT, 3-(4,5-dimethylthiazol-2-yl)-2,5-diphenyl-tetrazolium bromide; SE, standard error; VH, vehicle treated group; OD, optical density.

examined by flow cytometry, and no significant difference was observed in the percentage of splenic $\mathrm{CD}^{+}, \mathrm{CD} 8^{+}$and B220 ${ }^{+}$cells among NA, VH- and iron oxide nanoparticletreated groups (Table 1). To further investigate the potential influence of iron oxide nanoparticles on $\mathrm{T}$ cell reactivity, splenocytes were stimulated with the T-cell mitogen ConA $(5 \mu \mathrm{g} / \mathrm{mL})$ for 48 hours and their viability was measured. Interestingly, the viability of ConA-stimulated splenocytes was not affected by treatment with iron oxide nanoparticles (Figure 4B).

\section{Discussion}

Nanotechnology has been increasingly applied in various fields, such as nanomedicine. A common application of nanomedicine is the clinical use of superparamagnetic iron oxide nanoparticles as contrast agents to enhance magnetic resonance imaging. Previous studies have shown that a considerable portion of systemically administered iron oxide nanoparticles is taken up by the reticuloendothelial system leading to a potential exposure of immune cells to high concentrations of the nanoparticles..$^{5-7,23,24}$ Although a few studies demonstrated that iron oxide nanoparticles affected the functionality of macrophages and lymphocytes, ${ }^{10,25,26}$ evidence pertaining to the influence of iron oxide nanoparticles on antigen-specific immunity is scarce. In the present study, we investigated the in vivo effect of iron oxide nanoparticles on systemic antibody production and $\mathrm{T}$ cell responses in mice sensitized with OVA. Our data demonstrated that a single intravenous administration of iron oxide nanoparticles significantly attenuated the subsequent production of antigen-specific antibodies, as evidenced by a marked reduction in the serum levels of OVA-specific $\operatorname{IgG}_{1}$ and $\operatorname{IgG}_{2 \mathrm{a}}$ (Figure 2). The viability and cytokine production by splenocytes re-stimulated with the antigen OVA were also suppressed by iron oxide nanoparticles (Figures 3 and 4). In contrast, the viability of splenocytes stimulated with ConA, a $\mathrm{T}$ cell mitogen, was unaltered. Collectively, these results indicate that systemic exposure to a single dose of iron oxide nanoparticles differentially suppressed antigen-specific $\mathrm{T}$ cell

Table I Exposure to iron oxide nanoparticles did not affect splenocyte cellularity

\begin{tabular}{|c|c|c|c|c|c|c|}
\hline & \multirow[t]{2}{*}{ NA } & \multirow[t]{2}{*}{ OVA } & \multirow[t]{2}{*}{ VH } & \multicolumn{3}{|c|}{ Iron oxide nanoparticles (mg Fe/kg) } \\
\hline & & & & 10 & 30 & 60 \\
\hline $\mathrm{CD}^{+}(\%)$ & $25.4 \pm 0.8$ & $25.4 \pm \mathrm{I} . \mathrm{I}$ & $24.8 \pm 1.1$ & $25.5 \pm 0.6$ & $24.5 \pm 0.5$ & $24.6 \pm 0.6$ \\
\hline CD8 ${ }^{+}(\%)$ & $10.1 \pm 0.5$ & $9.1 \pm 0.6$ & $9.2 \pm 0.5$ & $10.0 \pm 0.5$ & $9.5 \pm 0.8$ & $8.6 \pm 0.2$ \\
\hline $\mathrm{B} 220^{+}(\%)$ & $51.0 \pm 1.0$ & $46.1 \pm 0.3$ & $46.1 \pm 1.0$ & $47.3 \pm 1.0$ & $48.3 \pm 0.6$ & $47.8 \pm 0.5$ \\
\hline
\end{tabular}

Notes: Splenocytes were prepared as described in the materials and methods. The percentage of $\mathrm{CD}^{+}, \mathrm{CD}^{+}$and $\mathrm{B} 220^{+}$cells was determined by flow cytometry. The data are expressed as the mean $\pm S E$ of 3 experiments.

Abbreviations: NA, naive; OVA, ovalbumin; $\mathrm{VH}$, vehicle. 
responses, in which the suppression of antigen-specific cytokine production may be attributed to a reduced viability of OVA-stimulated splenocytes.

$\mathrm{T}$ Helper (Th) cell-derived cytokines play a critical role in the activation and differentiation of $\mathrm{B}$ cells..$^{27} \mathrm{In}$ particular, the class switching from $\operatorname{IgM}$ to $\operatorname{IgG}_{2 \mathrm{a}}$ and $\operatorname{IgG}_{1}$ is dictated by Th1 (ie, IFN- $\gamma$ ) and Th2 (ie, IL-4) cytokines, respectively. ${ }^{27}$ In line with the attenuation of $\operatorname{IgG}_{2 \mathrm{a}}$ and $\operatorname{IgG}_{1}$, both IFN- $\gamma$ and IL-4 were suppressed in response to iron oxide nanoparticle exposure, suggesting that the attenuated antibody production may be attributed to the changes in Th cell functions. This notion is further substantiated by our data showing that the viability of splenocytes restimulated with the sensitized antigen OVA was attenuated by iron oxide nanoparticles. However, involvement of other immune cells cannot be ruled out. Antibody production is a complex process that requires interactions among various immune cells and the action of many mediators. Thus, in addition to $\mathrm{T}$ cells, other targets and/or mediators may be affected by iron oxide nanoparticles and contribute to the impaired humoral immunity. For example, a recent study showed that the capability of dendritic cells to process antigen and stimulate $\mathrm{T}$ cell cytokine expression was suppressed by exposure to iron oxide nanoparticles in vitro. ${ }^{28}$ Since OVA is a $\mathrm{T}$ cell-dependent antigen that requires to be processed and presented by antigen-presenting cells, ${ }^{29}$ we postulated that antigen presenting cells may be also involved in iron oxide nanoparticle-mediated attenuation of antibody production. This notion is indirectly supported by our data showing that the activation of splenocytes by ConA, whose responses are not antigen-specific, was not influenced by iron oxide nanoparticles. Further studies are required to determine whether the functionality of antigenpresenting cells is modulated by iron oxide nanoparticles in vivo.

Resovist ${ }^{\circledR}$ has been used clinically as a liver-specific magnetic resonance (MR) contrast agent; for this indication the recommended dose range is between $0.42-0.65 \mathrm{mg} \mathrm{Fe} / \mathrm{kg}$ in humans. Notably, a wider range of doses (0.14-22.4 mg Fe $/ \mathrm{kg}$ ) of Resovist ${ }^{\circledR}$ have been applied in rats for tracking MR signals in the liver. ${ }^{21} \mathrm{In}$ addition to liver contrasting, Resovist ${ }^{\circledR}$ at greater doses has been employed for imaging other tissues. For example, doses between $0.56-65 \mathrm{mg} \mathrm{Fe} / \mathrm{kg}$ have been used to assess musculoskeletal infections in rats. ${ }^{22}$ Based on these lines of evidence, the dose range $(10-60 \mathrm{mg} / \mathrm{kg}$ ) used in our studies could be pharmacologically relevant for certain applications of iron oxide nanoparticles.
The production of $\operatorname{IgG}_{2 \mathrm{a}}$ and IFN- $\gamma$, but not $\operatorname{IgG}_{1}$ and IL-4, was suppressed by the low dose of iron oxide nanoparticles (10 mg Fe/kg), whereas all the measured IgG and cytokines were attenuated by the higher doses ( 30 and $60 \mathrm{mg} \mathrm{Fe} / \mathrm{kg}$ ). These results suggest a differential sensitivity between Th1 and Th2 responses to iron oxide nanoparticles, in which the Th1 immunity is slightly more sensitive to iron oxide nanoparticles. A previous report has shown that intratracheal administration of mice with iron oxide nanoparticles affected inflammation and $\mathrm{T}$ cell cytokine expression in the airways. ${ }^{25}$ Given the pivotal role of Th cells in antigen-specific immunity, systemic exposure to iron oxide nanoparticles may have a potential impact on the host immune responses to antigens. On one hand, iron oxide nanoparticle-mediated attenuation of $\mathrm{T}$ cell responses may be beneficial to people predisposed to allergy. On the other hand, the suppressed $\mathrm{T}$ cell immunity may be detrimental in situations where an appropriate immune response is necessary for the protection of the host.

\section{Conclusion}

The present study demonstrates that a single intravenous administration of iron oxide nanoparticles markedly suppresses $\mathrm{T}$ cell-mediated immune reactions with a broad spectrum covering both Th1- and Th2-type responses. We speculate that systemic exposure to iron oxide nanoparticles may have an impact on host immunity in response to specific antigens. On the base of these results, the immunomodulatory property of iron oxide nanoparticles warrants further and more comprehensive investigation.

\section{Acknowledgments}

This work was supported by grants NSC98-2320-B-002-036MY3 from the National Science Council, and 99AS-9.2.5BQ-B1(2) from the Council of Agriculture, Executive Yuan, Taiwan.

\section{Disclosure}

The authors declare no conflicts of interest relevant to this study.

\section{References}

1. Liong M, Lu J, Kovochich M, et al. Multifunctional inorganic nanoparticles for imaging, targeting, and drug delivery. ACS Nano. 2008;2(5):889-896.

2. Xie J, Huang J, Li X, Sun S, Chen X. Iron oxide nanoparticle platform for biomedical applications. Curr Med Chem. 2009;16(10):1278-1294.

3. Yu MK, Jeong YY, Park J, et al. Drug-loaded superparamagnetic iron oxide nanoparticles for combined cancer imaging and therapy in vivo. Angew Chem Int Ed Engl. 2008;47(29):5362-5365. 
4. Chouly C, Pouliquen D, Lucet I, Jeune JJ, Jallet P. Development of superparamagnetic nanoparticles for MRI: effect of particle size, charge and surface nature on biodistribution. J Microencapsul. 1996;13(3):245-255.

5. Wang J, Chen Y, Chen B, et al. Pharmacokinetic parameters and tissue distribution of magnetic $\mathrm{Fe}(3) \mathrm{O}(4)$ nanoparticles in mice. Int J Nanomedicine. 2010;5:861-866.

6. Hamm B, Staks T, Taupitz M, et al. Contrast-enhanced MR imaging of liver and spleen: first experience in humans with a new superparamagnetic iron oxide. J Magn Reson Imaging. 1994;4(5):659-668.

7. Reimer P, Muller M, Marx C, et al. T1 effects of a bolus-injectable superparamagnetic iron oxide, SH U 555A: dependence on field strength and plasma concentration-preliminary clinical experience with dynamic T1-weighted MR imaging. Radiology. 1998;209(3):831-836.

8. Schipper ML, Cheng Z, Lee SW, et al. microPET-based biodistribution of quantum dots in living mice. J Nucl Med. 2007;48(9): 1511-1518.

9. Yamago S, Tokuyama H, Nakamura E, et al. In vivo biological behavior of a water-miscible fullerene: 14C labeling, absorption, distribution, excretion and acute toxicity. Chem Biol. 1995;2(6):385-389.

10. Hsiao JK, Chu HH, Wang YH, et al. Macrophage physiological function after superparamagnetic iron oxide labeling. NMR Biomed. 2008; 21(8):820-829.

11. Lunov O, Syrovets T, Buchele B, et al. The effect of carboxydextrancoated superparamagnetic iron oxide nanoparticles on c-Jun N-terminal kinase-mediated apoptosis in human macrophages. Biomaterials. 2010; 31(19):5063-5071.

12. Cho WS, Cho M, Kim SR, et al. Pulmonary toxicity and kinetic study of Cy5.5-conjugated superparamagnetic iron oxide nanoparticles by optical imaging. Toxicol Appl Pharmacol. 2009;239(1):106-115.

13. Chen BA, Jin N, Wang J, et al. The effect of magnetic nanoparticles of $\mathrm{Fe}(3) \mathrm{O}(4)$ on immune function in normal ICR mice. Int J Nanomedicine. 2010;5:593-599.

14. Dearman RJ, Caddick H, Basketter DA, Kimber I. Divergent antibody isotype responses induced in mice by systemic exposure to proteins: a comparison of ovalbumin with bovine serum albumin. Food Chem Toxicol. 2000;38(4):351-360.

15. Vora KA, Porter G, Peng R, et al. Genetic ablation or pharmacological blockade of dipeptidyl peptidase IV does not impact T cell-dependent immune responses. BMC Immunol. 2009;10:19.

16. Beck L, Spiegelberg HL. The polyclonal and antigen-specific IgE and IgG subclass response of mice injected with ovalbumin in alum or complete Freund's adjuvant. Cell Immunol. 1989;123(1):1-8.
17. Morokata T, Ishikawa J, Yamada T. Antigen dose defines T helper 1 and $\mathrm{T}$ helper 2 responses in the lungs of $\mathrm{C} 57 \mathrm{BL} / 6$ and BALB/c mice independently of splenic responses. Immunol Lett. 2000;72(2):119-126.

18. Schatz AR, Koh WS, Kaminski NE. Delta 9-tetrahydrocannabinol selectively inhibits T-cell dependent humoral immune responses through direct inhibition of accessory T-cell function. Immunopharmacology. 1993;26(2):129-137.

19. Jan TR, Su ST, Wu HY, Liao MH. Suppressive effects of cannabidiol on antigen-specific antibody production and functional activity of splenocytes in ovalbumin-sensitized BALB/c mice. Int Immunopharmacol. 2007;7(6):773-780.

20. Mosmann T. Rapid colorimetric assay for cellular growth and survival: application to proliferation and cytotoxicity assays. J Immunol Methods. 1983;65(1-2):55-63.

21. Lawaczeck R, Bauer H, Frenzel T, et al. Magnetic iron oxide particles coated with carboxydextran for parenteral administration and liver contrasting. Pre-clinical profile of SH U 555A. Acta Radiol. 1997;38(4 Pt 1):584-597.

22. Lee SM, Lee SH, Kang HY, et al. Assessment of musculoskeletal infection in rats to determine usefulness of SPIO-enhanced MRI. AJR Am J Roentgenol. 2007;189(3):542-548.

23. Pouliquen D, Le Jeune JJ, Perdrisot R, Ermias A, Jallet P. Iron oxide nanoparticles for use as an MRI contrast agent: pharmacokinetics and metabolism. Magn Reson Imaging. 1991;9(3):275-283.

24. Ferrucci JT, Stark DD. Iron oxide-enhanced MR imaging of the liver and spleen: review of the first 5 years. AJR Am J Roentgenol. 1990; 155(5):943-950

25. Park EJ, Kim H, Kim Y, Yi J, Choi K, Park K. Inflammatory responses may be induced by a single intratracheal instillation of iron nanoparticles in mice. Toxicology. 2010;275(1-3):65-71.

26. Ying E, Hwang HM. In vitro evaluation of the cytotoxicity of iron oxide nanoparticles with different coatings and different sizes in A3 human T lymphocytes. Sci Total Environ. 2010;408(20):4475-4481.

27. Finkelman FD, Holmes J, Katona IM, et al. Lymphokine control of in vivo immunoglobulin isotype selection. Annu Rev Immunol. 1990; 8:303-333.

28. Blank F, Gerber P, Rothen-Rutishauser B, et al. Biomedical nanoparticles modulate specific CD4(+) T cell stimulation by inhibition of antigen processing in dendritic cells. Nanotoxicology. 2011 Jan 13. [Epub ahead of print].

29. Vidard L, Rock KL, Benacerraf B. Heterogeneity in antigen processing by different types of antigen-presenting cells. Effect of cell culture on antigen processing ability. J Immunol. 1992;149(6):1905-1911.
International Journal of Nanomedicine

\section{Publish your work in this journal}

The International Journal of Nanomedicine is an international, peerreviewed journal focusing on the application of nanotechnology in diagnostics, therapeutics, and drug delivery systems throughout the biomedical field. This journal is indexed on PubMed Central,

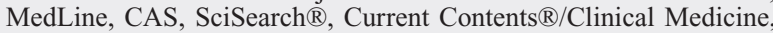

\section{Dovepress}

Journal Citation Reports/Science Edition, EMBase, Scopus and the Elsevier Bibliographic databases. The manuscript management system is completely online and includes a very quick and fair peer-review system, which is all easy to use. Visit http://www.dovepress.com/ testimonials.php to read real quotes from published authors. 